\title{
Distribusi dan Pemetaan Bentuk/Jenis Karya Sastra yang Tumbuh dan Berkembang pada Masyarakat Tutur Bahasa Bugis di Kabupaten Sumbawa
}

\author{
Syaiful Bahri*)
}

\begin{abstract}
Abstrak
Tulisan ini akan menggambarkan dua hal, yaitu: (1) deskripsi bentuk dan jenis karya sastra yang tumbuh dan berkembang pada masyarakat tutur bahasa Bugis di Kabupaten Sumbawa; (2) distribusi dan penyebaran karya sastra tersebut.

Dari hasil analisis data ditemukan dua ragam karya sastra, yaitu prosa dan puisi. Dari ragam prosa ditemukan dua jenis karya sastra, yaitu dongeng dan legenda yang kesemuanya ditemukan di kedua daerah pengamatan. Pengelompokan lebih khusus menunjukkan, di Teluk Santong hanya ditemukan jenis dongeng lelucon, sedangkan di Labuan Mapin ditemukan tiga jenis dongeng, yaitu lelucon, fabel, dan dongeng biasa. Jenis legenda di Teluk Santong hanya legenda setempat, sedangkan di Labuan Mapin ditemukan legenda perorangan, keagamaan, dan alam gaib.

Ragam puisi ditemukan jenis pantun (kélong) dan mantra (jappi). Jenis pantun ditemukan di kedua daerah pengamatan, sedangkan jenis Mantra hanya ditemukan di Labuan Mapin.
\end{abstract}

Kata Kunci: Sastra Bugis, dekripsi, distribusi, prosa, puisi (élong)

\section{Pengantar}

Dalam kehidupan sehari-hari kita sering menandai atau membedakan seseorang dengan orang lain berdasarkan ciri dan kekhasannya. Ketika melihat orang putih dengan mata sipit, pikiran kita sering diarahkan pada anggapan bahwa orang itu adalah orang Cina atau Jepang. Di lain pihak, kita menandai seseorang berasal dari NTT maupun Papua karena melihat rambutnya yang keriting dan kulit gelapnya.

\footnotetext{
*) Sarjana Pendidikan, Pembantu Pimpinan pada Kantor Bahasa Prov. NTB
} 
Kesimpulan atau anggapan berdasarkan ciri seperti yang disebutkan di atas tidak bisa kita salahkan, namun penggeneralisasian orang sipit berkulit sebagai orang Cina/Jepang atau orang berambut keriting dan berkulit gelap sebagai orang NTT/Papua bisa dikatakan sebagai penggeralisasian yang keliru. Banyak kita temukan orang yang berkulit putih dengan mata sipit, tetapi bukan orang Jepang/Cina. Tidak sedikit pula kita temukan orang berambut keriting dengan kulit gelap, namun bukan orang NTT/Papua.

Salah satu ciri atau penanda yang paling jelas dan tak bisa terbantahkan untuk menandai seseorang adalah dari segi bahasa yang digunakan. Dalam konteks Indonesia, kita akan mengetahui asal atau etnis seseorang ketika menggunakan bahasanya.

Jika kita merujuk pada agama, manusia pertama yang diciptakan Tuhan adalah Adam yang berpasangan dengan Hawa. Adam dan Hawa inilah yang melahirkan keturunan yang kemudian berkembang menjadi manusia seperti sekarang ini. Pada awalnya mereka memiliki bahasa yang satu, namun karena terpencar dan sulitnya komunikasi menjadikan mereka tumbuh dan berkembang secara sendiri-sendiri sesuai dengan kondisi alam dan lingkungan geografis masing-masing. Dalam jangka waktu yang sangat lama mereka sudah tidak saling memahami dan pada tahap selanjutnya mereka membentuk identitas kelompok masing-masing menjadi suku-suku dengan aturan sosial yang diciptakan berdasarkan kesepakatan bersama. Suku-suku ini pun terkenal dengan pulau-pulau yang mereka tempati.

Kasus yang terjadi pada bahasa tersebut tentunya akan diikuti oleh sastra karena sastra menggunakan bahasa sebagai medianya. Adanya penyebutan bahasa yang didasarkan pada nama suku secara otomatis akan diikuti oleh sastra sehingga di Indonesia kita kenal sastra Mbojo, 
Samawa, Sasak, Bugis, dan lain-lain. Penyebutan sastra berdasarkan nama suku disebabkan karya sastra tersebut dianggap sebagai milik bersama. Sebagai salah satu hasil budaya, maka sastra yang dianggap sebagai milik bersama tersebut merupakan bagian dari folklor.

Sebagai sebuah karya yang dikatakan milik bersama, seorang ahli folklor Amerika, Jan Harold Brunvand (dalam Danandjaja, 1997: 21), menggolongkan folklor dalam tiga kelompok besar, yaitu: (1) folklor lisan (verbal folklore), (2) folklor sebagian lisan (partly verbal folklore), dan (3) folklore bukan lisan (non-verbal folklore).

Perkembangan transportasi memudahkan orang berpindah dari satu tempat ke tempat lain. Dengan berbagi alasan dan motivasi, masingmasing kelompok yang sudah melekatkan identitasnya dengan suku tersebut berpindah dari pulau yang mereka tempati ke pulau lain yang notabene sudah didiami oleh suku dengan bahasa, sastra, adat yang yang berbeda. Hal inilah yang terjadi pada suku Bugis yang menempati pulau yang sudah didiami oleh mayoritas suku Samawa. Sebagai mahluk sosial, proses interaksi pun tak kan terhindarkan. Berlangsungnya proses interaksi didasarkan pada berbagai faktor, antara lain, faktor imitasi, sugesti, identifikasi, dan simpati. (Soekanto, $1990: 63$ )

Kebertahanan sastra pada masyarakat tutur bahasa Bugis yang minoritas di tengah mayoritas sastra pada masyarakat tutur bahasa Samawa sangat menarik untuk dikaji. Dari tulisan ini diharapkan akan bisa menjawab dua permasalahan, yaitu: (1) deskripsi bentuk dan jenis karya sastra yang tumbuh dan berkembang pada masyarakat tutur bahasa Bugis di Kabupaten Sumbawa; (2) sebaran geografis bentuk dan jenis karya sastra yang tumbuh dan berkembang pada masyarakat tutur bahasa Bugis di Kabupaten Sumbawa. 


\section{Pembahasan}

\subsection{Deskripsi Bentuk dan Jenis Karya Sastra}

Pendeskripsian bentuk dan jenis karya sastra ini akan dipaparkan berdasarkan daerah pengamatan, yaitu Labuan Mapin dan Teluk Santong. Secara umum di kedua daerah pengamatan bentuk Prosa Rakyat dan Puisi Rakyat. Lathief (2003) mengatakan, cerita atau kisah dalam masyarakat Bugis disebut dengan istilah pau-pau, sedangkan puisi (syair) diistilahkan dengan élong. Istilah untuk puisi ini disamakan dengan istilah yang digunakan untuk lagu-lagu rakyat atau nyanyian. Sedangkan, salah satu jenis kegiatan berpuisi, yaitu berpantun disebut makelong. Dalam tulisan ini, istilah pau-pau akan digunakan secara bergantian dengan istilah prosa rakyat. Istilah élong akan dipakai bergantian dengan istilah puisi rakyat, sedangkan istilah kelong dipakai bergantian dengan pantun. Pemakaian secara bergantian tersebut dilakuikan karena dianggap memiliki pengertian yang sama.

\subsubsection{Bentuk dan Jenis Karya Sastra di Labuan Mapin}

Seperti sudah dijelaskan di atas, bentuk karya sastra yang ditemukan di Labuan Mapin adalah Prosa Rakyat (pau-pau) dan Puisi Rakyat (élong). Prosa Rakyat yang ditemukan sebanyak sebelas judul cerita. Kesebelas cerita tersebut dapat digolongkan menjadi dua jenis, yaitu dongeng dan legenda (attoriolong). 
Tabel 1

Jenis Prosa/Pau-Pau di Desa Labuan Mapin

\begin{tabular}{|c|c|c|}
\hline NO. & $\begin{array}{c}\text { JENIS } \\
\text { PAU-PAU }\end{array}$ & JUDUL PAU-PAU \\
\hline 1. & Dongeng & $\begin{array}{l}\text { 1. Nene na Latok (Kakek dan Nenek) } \\
\text { 2. Paqke Masselessurang (Empat Bersaudara) } \\
\text { 3. Jonga Sibawa Alapung (Rusa dan Siput) } \\
\text { 4. Luwi Masselessurang (Tiga Bersaudara) } \\
\text { 5. (Si Jago Rencana) } \\
\text { 6. Pulandoq Sibawa Buaja (Kancil dan } \\
\text { Buaya) } \\
\text { 7. Pangampi (Si Penggembala) }\end{array}$ \\
\hline 2. & $\begin{array}{l}\text { Legenda/Att } \\
\text { oriolong }\end{array}$ & $\begin{array}{l}\text { 1. Abdullah Sallafi } \\
\text { 2. Parontak Kahar Muzakar (Pemberontakan } \\
\text { Kahar Muzakar) } \\
\text { 3. Kuburuk Hassanuddin } \\
\text { Hassanuddin) } \\
\text { Aga Sabakna Namaega Tau Masali Massapi E } \\
\text { (Apa Sebabnya Ikan Masssapi Tidak Boleh } \\
\text { Dimakan) }\end{array}$ \\
\hline
\end{tabular}

Berdasarkan penggolongan dongeng yang dilakukan Anti Aarne dan Stith Thompson (dalam Pandetia, 2003: 85) maka dongeng yang ditemukan di daerah pengamatan Labuan Mapin digolongkan menjadi tiga jenis, yaitu: dongeng biasa (ordinary folktales), dongeng binatang (animal tales), dan dongeng lelucon dan anekdot (jokes and anecdotes folktales). 
Tabel 2

Penggolongan Dongeng Pada Masyarakat Tutur Bahasa Bugis di Labuan Mapin Berdasarkan Teori yang Dikemukakan Oleh Anti Aarne dan Thompson

\begin{tabular}{|c|c|c|c|}
\hline No. & Judul & Jenis & Ciri-Ciri \\
\hline 1. & $\begin{array}{l}\text { Latok na Nene } \\
\text { (Kakek dan Nenek) }\end{array}$ & $\begin{array}{l}\text { Dongeng } \\
\text { Biasa }\end{array}$ & $\begin{array}{l}\text { - Cerita ditokohi oleh } \\
\text { manusia. } \\
\text { - Berkisah tentang } \\
\text { suka-duka seseorang. }\end{array}$ \\
\hline 2. & $\begin{array}{l}\text { Paqke } \\
\text { Masselessurang } \\
\text { (Empat Bersaudara) }\end{array}$ & $\begin{array}{l}\text { Dongeng } \\
\text { Biasa }\end{array}$ & $\begin{array}{l}\text { - Cerita ditokohi oleh } \\
\text { manusia. } \\
\text { - Berkisah tentang } \\
\text { suka-duka seseorang. }\end{array}$ \\
\hline 3. & $\begin{array}{l}\text { Jonga Sibawa } \\
\text { Alapung (Rusa dan } \\
\text { Kura-Kura) }\end{array}$ & Fabel & $\begin{array}{l}\text { - Cerita ditokohi oleh } \\
\text { binatang. } \\
\text { - Tokoh binatang } \\
\text { tersebut bertingkah } \\
\text { laku seperti manusia. }\end{array}$ \\
\hline 4. & $\begin{array}{l}\text { Luwi } \\
\text { Masselessurang } \\
\text { (Tiga Bersaudara) }\end{array}$ & $\begin{array}{l}\text { Dongeng } \\
\text { Biasa }\end{array}$ & $\begin{array}{l}\text { - Cerita ditokohi oleh } \\
\text { manusia } \\
\text { - Berkisah tentang } \\
\text { suka-duka seseorang }\end{array}$ \\
\hline 5. & $\begin{array}{l}\text { I Jago Rencana (Si } \\
\text { Jago Rencana) }\end{array}$ & $\begin{array}{l}\text { Dongeng } \\
\text { Lelucon }\end{array}$ & $\begin{array}{l}\text { - Cerita bersifat } \\
\text { lucu/humor atau } \\
\text { menimbulkan tawa }\end{array}$ \\
\hline 6. & $\begin{array}{l}\text { Pulandoq Sibawa } \\
\text { Buaja (Kancil dan } \\
\text { Buaya) }\end{array}$ & Fabel & $\begin{array}{l}\text { - Cerita ditokohi oleh } \\
\text { binatang. } \\
\text { - Tokoh binatang } \\
\text { tersebut bertingkah } \\
\text { laku seperti manusia. }\end{array}$ \\
\hline 7. & $\begin{array}{lr}\text { I Pangampi } & \text { (Si } \\
\text { Penggembala) } & \end{array}$ & $\begin{array}{l}\text { Dongeng } \\
\text { Lelucon }\end{array}$ & $\begin{array}{l}\text { - Cerita bersifat } \\
\text { lucu/humor atau } \\
\text { menimbulkan tawa }\end{array}$ \\
\hline
\end{tabular}

Sama halnya dengan dongeng, legenda yang terdapat di Labuan Mapin juga dapat digolong menjadi beberapa jenis legenda dengan mengacu pada teori penggolongan legenda yang dikemukakan oleh Jan Harold Brunvand (dalam Danandjaja, 1997: 67), yaitu: legenda 
keagamaan (religious legends), legenda alam gaib (supernatural legends), dan legenda perorangan (personal legends).

\section{Tabel 3}

Penggolongan Legenda Pada Masyarakat Tutur Bahasa Bugis di Desa Labuan Mapin Berdasarkan Teori yang Dikemukakan

Jan Harold Brunvand

\begin{tabular}{|c|c|c|c|}
\hline No. & Judul Legenda & Jenis Legenda & Ciri-Ciri \\
\hline 1. & Abdullah Salafi & $\begin{array}{l}\text { Legenda } \\
\text { keagamaan }\end{array}$ & $\begin{array}{l}\text { - Dianggap benar-benar } \\
\text { terjadi } \\
\text { - Tempat terjadinya di } \\
\text { dunia yang kita kenal } \\
\text { sekarang } \\
\text { - Menceritakan tentang } \\
\text { tokoh orang saleh }\end{array}$ \\
\hline 2. & $\begin{array}{l}\text { Pemberontakan } \\
\text { Kahar Muzakar }\end{array}$ & $\begin{array}{l}\text { Legenda } \\
\text { Perorangan }\end{array}$ & $\begin{array}{l}\text { - Dianggap benar-benar } \\
\text { terjadi } \\
\text { - Tempat terjadinya di } \\
\text { dunia yang kita kenal } \\
\text { sekarang } \\
\text { - Menceritakan tentang } \\
\text { tokoh tertentu } \\
\end{array}$ \\
\hline 3. & $\begin{array}{l}\text { Aga Sabakna } \\
\text { Namaega Tau } \\
\text { Masali Masapi } \\
\text { E }\end{array}$ & $\begin{array}{l}\text { Legenda alam } \\
\text { gaib }\end{array}$ & $\begin{array}{l}\text { - Dianggap benar-benar } \\
\text { terjadi } \\
\text { - Tempat terjadinya di } \\
\text { dunia yang kita kenal } \\
\text { sekarang } \\
\text { - Pernah dialami } \\
\text { sesorang/masyarakat } \\
\text { - Meneguhkan kebenaran } \\
\text { takhayul/kepercayaan } \\
\text { rakyat }\end{array}$ \\
\hline 4. & $\begin{array}{l}\text { Makam } \\
\text { Hasanuddin }\end{array}$ & $\begin{array}{l}\text { Legenda } \\
\text { perorangan }\end{array}$ & $\begin{array}{l}\text { - Dianggap benar-benar } \\
\text { terjadi } \\
\text { - Tempat terjadinya di } \\
\text { dunia yang kita kenal } \\
\text { sekarang } \\
\text { - Menceritakan tentang } \\
\text { tokoh tertentu }\end{array}$ \\
\hline
\end{tabular}


Selain Prosa Rakyat, bentuk Puisi rakyat juga ditemukan di daerah Labuan Mapin. Jenis puisi rakyat yang ditemukan adalah Mantra/Jampi (jappi) dan Pantun (berpantun = makelong).

Jenis jappi yang ditemukan ada tiga macam, yaitu jappi pancara, siluka, dan jappi Lesseqko anginge. Jappi pancara adalah mantra yang digunakan pada saat membuat perahu. Jappi jenis ini tidak terikat pada kata atau kalimat yang digunakan. Diksi atau pilihan kata yang digunakan adalah kata-kata yang biasa dipakai dalam kehidupan sehari-hari, tergantung niat atau keinginan kita terhadap perahu yang akan dibuat. Meskipun begitu, setelah kata-kata tersebut digabung menjadi sebuah kalimat utuh, makna yang ada dihasilkan tidak muncul secara langsung, implisit. Hal ini dapat kita lihat dari data berikut:

Kuanrememenge asseleqna loviku (Saya memakan hasil perahu saya baru saya kerjakan)

Jappi siluka adalah jappi yang dilakukan saat akan melakukan akad nikah. Jappi ini dibacakan oleh seorang ayah kepada anaknya yang akan melakukan pernikahan. Hal ini dilakukan dengan cara mempertemukan ibu jari sang ayah dengan ibu jari anaknya yang akan menikah. Seperti halnya jappi pancara, jappi siluka ini tidak terikat pada kata-kata yang akan digunakan. Pilihan kata yang digunakan merupakan kata-kata yang digunakan dalam kehidupan sehari-hari. Sang Ayah bisa menggunakan kata atau kalimat apa saja tergantung niat. Kalimat yang dihasilkan dalam mantra tersebut juga mengandung makna yang implisit, seperti terlihat dalam data berikut:

Kuacing atimu (Saya bersihkan hatimu)

Kuala eloqmu (Kuambil kemauanmu)

Kurepung cina matanmu (Saya kumpulkan penglihatanmu) 
Jappi lesseqko anginge adalah jappi yang disampaikan dengan tujuan mengusir angin. Hal ini tidak terlepas dari kehidupan orang Bugis sebagai suku pelaut. Jappi ini diucapkan oleh seorang nelayan ketika menemukan angin puting beliung saat berada di tengah laut. Setelah jappi tersebut dibacakan, orang yang membacanya harus mengarahkan telunjuknya ke arah yang diinginkan dengan harapan angin tersebut tidak mendekati perahu yang ditumpangi. Berbeda dengan kedua jenis jappi di atas, jappi lesseqko anginge ini mengandung makna eksplisit. Jappi ini seolah-olah menganggap angin sebagai mahluk hidup yang bisa diajak berdialog. Untuk itu, kalimat-kalimat yang ada di dalamnya merupakan kalimat-kalimat perintah yang memerintahkan angin tersebut menghindar, tidak mendekati perahu yang ditumpangi. Mantra tersebut dapat dilihat dalam data berikut:

Ikolasona anginge (Kamu angin)

Lesseqko ajaq muatuju mai (Menghindar, jangan kesini)

Fada-fada taue (Sama-sama kita)

Difancaji difuange (Dijadikan oleh Tuhan)

Yannamilo iko (Hanya kamu)

Dialusuke monro (Di tempat halus kamu tinggal)

Lasona Nabi Adam (Kontol Nabi Adam)

Mancaji Laso angin (Jadi kontol angin)

Nabi Adam mutokoedi (Nabi Adam juga di sini)

Lesseqko (Menghindar)

Jenis elong lain yang juga ditemukan di Labuan Mappin adalah kelong atau pantun. Kegiatan makelong yang kadang dilagukan ini terdiri atas dua jenis, yaitu makellong pappaseng dan Tomalolo. Makellong pappeseng adalah kegiatan berpantun yang berisi nasihat. Jenis makelong seperti ini biasanya disampaikan oleh orang tua yang diminta memberikan sambutan pada acara pernikahan. Untuk itu, 
nasihat yang disampaikan berisi peringatan-peringatan terhadap pengantin yang akan menjalani bahtera rumah tangga. Jenis makelong seperti ini dapat dilihat pada data berikut:

Bombang matuae (Gelombang menggulung, mertua)

Kala-kala ipae (Gelombang keras, ipar)

Pesiq petepengene (Karang, keluarga terdekat)

Yamatti minassakoq (Yang dinginkan/diidamkan tercapai)

Mewai siraga-raga (Berteman sepergaulan)

Turangga silae (Tidak was-was)

Berbeda dengan makellong pappeseng, makellong tomalolo merupakan kegiatan berpantun yang berisi kehidupan remaja atau muda-mudi. Kegiatan makellong tomalolo ini dilakukan dengan cara saling berbalasan (berbalas pantun) antara pihak pengantin laki-laki dan pihak pengantin perempuan. Kegiatan ini biasanya dilakukan pada saat acara buka pintu, manimpak boco, yaitu salah satu acara yang harus dilalui oleh pengantin laki-laki sebelum memasuki kamar pengantin yang di dalamnya sudah ada pengantin perempuan. Orang yang berpantun adalah wakil dari pangantin laki-laki dengan wakil dari pengantin perempuan. Wakil pengantin laki-laki berada di luar kamar bersama pengantin laki-laki, sedangkan wakil pengantin perempuan berada di dalam kamar bersama pengantin perempuan. Setelah kegiatan makelong ini dilakukan, barulah pengantin perempuan membukakan pintu kamar untuk pengantin laki-laki. Berikut ini adalah data yang ditemukan:

Pria:

Ketengero muita (Lihat bulan itu)

Aliliq alibunna (Lingkarannya bundar)

Atikkuq rilaling (Begitu pula hatiku di dalam) 
Perempuan:

Atikkuq milao tulung (Hatiku minta tolong)

Nyawakuq temma pettu (Nyawaku tak ada putusnya)

Sengeq ki watammu (Saya sudah serahkan padamu)

Perempuan:

Mau salaka sellelemmu (Walaupun perak salammu)

Ulawo pada tummu (Emas kirimanmu)

Watanmu paku tajam (Dirimu saja yang kutunggu)

\subsubsection{Bentuk dan Jenis Karya Sastra di Teluk Santong}

Ragam atau bentuk cerita rakyat/pau-pau yang ditemukan di Teluk Santong terdiri dari dua jenis dongeng dan attoriolong (legenda). Adapun judul dari jenis pau-pau tersebut dapat dilihat dalam tabel berikut:

\section{Tabel 4}

Jenis Prosa/Pau-Pau Pada Masyarakat Tutur Bahasa Bugis di Desa Teluk Santong

\begin{tabular}{|c|c|c|}
\hline NO. & JENIS PAU-PAU & JUDUL PAU-PAU \\
\hline 1. & Dongeng & $\begin{array}{ll}\text { 1. } & \text { Tau Bukuq dan Tau Batu } \\
\text { Cuping (Si Bungkuk dan Si } \\
\text { Sumbing) } \\
\text { 2. Dua Tau Uta (Dua Orang Buta) } \\
\text { 3. Menreq Kaluku (Memanjat } \\
\text { Kelapa) } \\
\text { 4. I Uta na I Keppang (Si Buta dan } \\
\text { Si Pincang) } \\
\text { 5. Mameng (Memancing) }\end{array}$ \\
\hline 2. & Attoriolong/legenda & $\begin{array}{l}\text { 1. Tanjung Manangis (versi Karim) } \\
\text { 2. Tanjung Manangis (versi Kahar) }\end{array}$ \\
\hline
\end{tabular}

Sama seperti data pada daerah pengamatan Labuan Mapin, data dongeng yang ditemukan di Teluk Santong juga diitentifikasi 
berdasarkan penggolongan dongeng yang dikemukakan oleh Anti Aarne dan Stith Thompson. Dari data yang ditemukan, di daerah pengamatan Teluk Santong terdapat satu jenis dongeng, yaitu dongeng lelucon dan anekdot (jokes and anecdotes folktales).

Tabel 5

Penggolongan Dongeng Pada Masyarakat Tutur Bahasa Bugis di Teluk Santong Berdasarkan Teori yang Dikemukakan oleh Anti Aarne dan Thompson

\begin{tabular}{|c|l|l|l|}
\hline No. & \multicolumn{1}{|c|}{ Judul } & \multicolumn{1}{c|}{ Jenis } & \multicolumn{1}{|c|}{ Ciri-Ciri } \\
\hline 1. & $\begin{array}{l}\text { I Bukuq dan I } \\
\text { Sumbing (Si } \\
\text { Bungkuk dan Si } \\
\text { Sumbing) }\end{array}$ & $\begin{array}{l}\text { Dongeng } \\
\text { Lelucon }\end{array}$ & $\begin{array}{l}\bullet \text { Cerita bersifat lucu/humor } \\
\text { atau menimbulkan tawa }\end{array}$ \\
\hline 2. & $\begin{array}{l}\text { Dua Tau Uta } \\
\text { (Dua Orang Buta) }\end{array}$ & $\begin{array}{l}\text { Dongeng } \\
\text { Lelucon }\end{array}$ & $\begin{array}{l}\bullet \text { Cerita bersifat lucu/humor } \\
\text { atau menimbulkan tawa }\end{array}$ \\
\hline 3. & $\begin{array}{l}\text { (Bungkuk dan Si } \\
\text { Sumbing) }\end{array}$ & $\begin{array}{l}\text { Dongeng } \\
\text { Lelucon }\end{array}$ & $\begin{array}{l}\bullet \text { Cerita bersifat lucu/humor } \\
\text { atau menimbulkan tawa }\end{array}$ \\
\hline 4. & $\begin{array}{l}\text { Menreq Kaluku } \\
\text { (Memanjat } \\
\text { Kelapa) }\end{array}$ & $\begin{array}{l}\text { Dongeng } \\
\text { Lelucon }\end{array}$ & $\begin{array}{l}\text { Cerita bersifat lucu/humor } \\
\text { atau menimbulkan tawa }\end{array}$ \\
\hline 5. & $\begin{array}{l}\text { I Uta na I } \\
\text { Keppang (Si Buta } \\
\text { dan Si Pincang) }\end{array}$ & $\begin{array}{l}\text { Lelucon } \\
\text { Dongeng } \\
\text { (Mameng } \\
\text { (Memancing) }\end{array}$ & $\begin{array}{l}\text { atau menimbulkan tawa } \\
\text { Lelucon }\end{array}$ \\
\hline
\end{tabular}


Sementara itu, jenis legenda atau attoriolong yang terdapat di Teluk Santong sangat berbeda dengan attoriolong yang terdapat di Labuan Mapin. Mengacu pada teori yang dikemukakan Brunvard, Di Teluk Santong terdapat satu jenis legenda yang tidak ditemukan di desa Labuan Mapin, yaitu legenda setempat (local legends).

\section{Tabel 6}

Jenis Legenda Pada Masyarakat Tutur Bahasa Bugis di Teluk Santong Berdasarkan Teori yang Dikemukakan Brunvard

\begin{tabular}{|l|l|l|l|}
\hline No. & \multicolumn{1}{|c|}{$\begin{array}{c}\text { Judul } \\
\text { Attoriolong }\end{array}$} & Jenis & Ciri-ciri \\
\hline 1. & $\begin{array}{l}\text { Tanjung Manangis } \\
\text { (versi Karim) }\end{array}$ & $\begin{array}{l}\text { Legenda } \\
\text { setempat }\end{array}$ & $\begin{array}{l}\text { - Dianggap benar-benar } \\
\text { terjadi } \\
\text { - Tempat terjadinya di dunia } \\
\text { yang kita kenal sekarang } \\
\text { Berhubungan dengan } \\
\text { nama suatu tempat }\end{array}$ \\
\hline 2. & $\begin{array}{l}\text { Tanjung Manangis } \\
\text { (versi Kahar) }\end{array}$ & $\begin{array}{l}\text { Legenda } \\
\text { setempat }\end{array}$ & $\begin{array}{l}\text { - Dianggap benar-benar } \\
\text { terjadi } \\
\text { Tempat terjadinya di dunia } \\
\text { yang kita kenal sekarang } \\
\text { Berhubungan dengan } \\
\text { nama suatu tempat }\end{array}$ \\
\hline
\end{tabular}

Sama seperti di Labuan Mapin, di Teluk Santong juga ditemukan karya sastra berbentuk puisi rakyat. Jika di Labuan Mapin ditemukan dua jenis puisi rakyat, di Teluk Santong hanya ditemukan satu jenis, yaitu pantun (makelong =berpantun). Ciri-ciri pantun yang ditemukan di Teluk Santong ini pun berbeda dengan ciri pantun yang ditemukan di Labuan Mapin. Konsep pantun di Teluk Santong sesuai dengan konsep pantun secara umum yang berciri setiap bait terdiri atas empat baris, baris pertama dan kedua merupakan sampiran, baris ketiga dan keempat merupakan isi, bersajak a-b-a-b atau a-a-a-a. Selain itu, pantun yang kami dapatkan menggunakan bahasa 
Indonesia sebagai media penyampaian. Ketika ditanyakan tentang keberadaan pantun yang berbahasa Bugis, informan memberikan pengakuan bahwa tidak ada pantun yang berbahasa Bugis. Adapaun élong atau pantun yang ditemukan adalah sebagai berikut.

Tinggi latinggi gunung Tambora

Di situ tempat burung garuda

Tinggi latinggi kantor bicara

Di situ tempat kita berdua

Di sana gunung di sini gunung

Di tengah-tengah kembang melati

Di sana bingung di sini bingung

Bersama-sama menahan hati

\section{2 Sebaran Geografis Bentuk dan Jenis Karya Sastra}

Meskipun Labuan Mapin dan Teluk Santong merupakan dua wilayah yang sebagian besar didiami oleh masyarakat etnis Bugis, namun keberadaan ragam maupun jenis karya sastra pada keduanya tidak menunjukkan keseragaman. Hal ini tentunya dipengaruhi oleh kondisi daerah maupun masyarakat pada masing-masing wilayah.

Jika kita melihat dari segi ragam, kedua wilayah memiliki ragam karya sastra yang sama, yakni ragam prosa dan puisi. Akan tetapi, jika kita melihat lebih khusus kepada jenis-jenis karya sastra yang ditemukan, kedua wilayah memiliki jenis yang sangat berbeda satu sama lain, misalnya pada daerah Labuan Mapin ditemukan jenis puisi mantra, sedangkan di daerah Teluk Santong jenis puisi tersebut tidak ditemukan. Perbandingan keberadaan jenis karya sastra tersebut akan lebih jelas jika kita melihat pada tabel-tabel di bawah ini. Agar terlihat lebih terinci, tabel-tebel tersebut akan dibagai berdasarkan ragam karya sastra yang ada pada kedua daerah pengamatan. 


\section{Tabel 7}

Keberadaan Jenis Karya Sastra Ragam Prosa di Labuan Mapin dan Teluk Santong

\begin{tabular}{|c|c|c|c|}
\hline No. & Jenis & Labuan Mapin & Teluk Santong \\
\hline \multirow[t]{3}{*}{1.} & \multirow[t]{3}{*}{ Dongeng } & - Dongeng Biasa & - Dongeng Lelucon \\
\hline & & - Dongeng Fabel & \\
\hline & & - Dongeng Lelucon & \\
\hline \multirow[t]{3}{*}{2.} & \multirow[t]{3}{*}{$\begin{array}{l}\text { Legenda/ } \\
\text { Attoriolong }\end{array}$} & $\begin{array}{l}\text { - Legenda } \\
\text { perorangan }\end{array}$ & - Legenda Setempat \\
\hline & & $\begin{array}{l}\text { - Legenda } \\
\text { Keagamaan }\end{array}$ & \\
\hline & & $\begin{array}{l}- \text { Legenda Alam } \\
\text { Ghaib }\end{array}$ & \\
\hline
\end{tabular}

Selain pada ragam prosa, keberadaan jenis karya sastra ragam puisi di Labuan Mapin menunjukkan jumlah yang lebih banyak jika dibandingkan dengan Teluk Santong. Dua jenis karya sastra ragam puisi yang ada di Labuan Mapin adalah pantun/kellong dan mantra/jappi, sedangkan di Teluk Santong hanya ditemukan jenis pantun/kellong. Pembagian jenis-jenis tersebut dalam bagian yang lebih khusus pun mengalami hal yang sama. Untuk lebih jelasnya dapat dilihat dari tabel berikut. 


\section{Tabel 8}

Keberadaan Jenis Karya Sastra Ragam Puisi

di Labuan Mapin dan Teluk Santong

\begin{tabular}{|c|c|c|c|}
\hline No. & Jenis & Labuan Mapin & Teluk Santong \\
\hline \multirow[t]{2}{*}{1.} & \multirow[t]{2}{*}{ Pantun/Kellong } & $\begin{array}{l}\text { - Kellong } \\
\text { Pappeseng } \\
\text { (pantun } \\
\text { nasihat) }\end{array}$ & $\begin{array}{l}\text { - Kellong Tomalolo } \\
\text { (pantun } \\
\text { remaja/muda- } \\
\text { mudi) }\end{array}$ \\
\hline & & $\begin{array}{l}\text { - Kelong } \\
\text { Tomalolo } \\
\text { (pantun } \\
\text { remaja/muda- } \\
\text { mudi) }\end{array}$ & \\
\hline \multirow[t]{2}{*}{2.} & \multirow[t]{2}{*}{ Mantra/Jappi } & - Jappi Siluka & \\
\hline & & $\begin{array}{l}\text { - Jappi Lesseqko } \\
\text { Anginge }\end{array}$ & \\
\hline
\end{tabular}

\section{Simpulan}

Berdasarkan hasil pengkajian data yang telah dilakukan, ragam karya sastra yang tumbuh dan berkembang pada masyarakat tutur bahasa Bugis di Kabupaten Sumbawa terdiri atas prosa dan puisi. Kedua ragam karya sastra tersebut terbagi atas beberapa jenis. Dalam ragam prosa terdapat jenis attoriolong (legenda) dan dongeng, sedangkan ragam puisi terdapat jenis èlong, kèlong, dan jappi-jappi. Ragam maupun jenis karya sastra tersebar di kedua daerah pengamatan, Labuhan Mapin dan Teluk Santong. Ragam, jenis, serta persebarannya tergambar dalam tabel berikut. 


\section{Tabel 19}

Ragam dan Jenis Karya Sastra yang Tumbuh dan Berkembang di Kabupaten Sumbawa

\begin{tabular}{|c|c|c|c|c|}
\hline No. & Ragam & $\begin{array}{c}\text { Jenis } \\
\text { Sastra }\end{array}$ & Judul/Kategori & Daerah Persebaran \\
\hline 1. & Prosa & Dongeng & 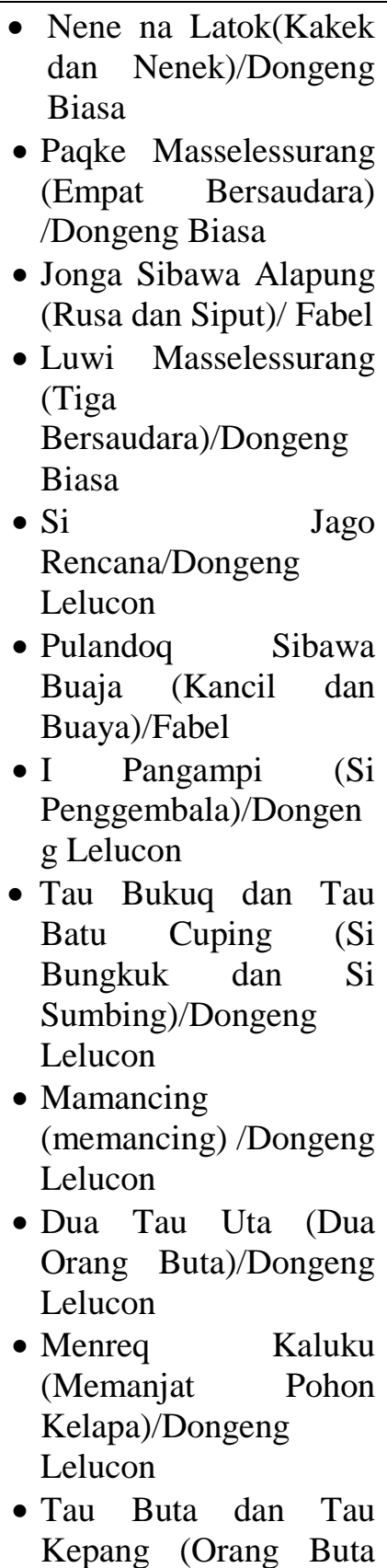 & $\begin{array}{l}\text { - Labuhan Mapin } \\
\text { - Labuhan Mapin } \\
\text { - Labuhan Mapin } \\
\text { - Labuhan Mapin } \\
\text { - Labuhan Mapin } \\
\text { - Labuhan Mapin } \\
\text { - Teluk Santong } \\
\text { - Tabuhan Mapin } \\
\text { - Teluk Santong }\end{array}$ \\
\hline
\end{tabular}




\begin{tabular}{|c|c|c|c|c|}
\hline & & $\begin{array}{c}\text { Attoriolo } \\
\text { ng/Legen } \\
\text { da }\end{array}$ & $\begin{array}{l}\text { dan Orang } \\
\text { Pincang)/Dongeng } \\
\text { Lelucon } \\
\text { - Abd. Salafi/Legenda } \\
\text { Keagamaan } \\
\text { - Parontak } \\
\text { Muzakar } \\
\text { (Pemberontakan Kahar } \\
\text { Muzakar)/Legenda } \\
\text { Perorangan } \\
\text { - Kaburuk Hasanuddin } \\
\text { (Makam } \\
\text { Hassanuddin)/Legenda } \\
\text { Perorangan } \\
\text { - Aga Sabakna } \\
\text { Namaega Tau Masali } \\
\text { Masapi E (Apa } \\
\text { Sebabnya Iakan } \\
\text { Masssapi Tidak Boleh } \\
\text { Dimakan)/Legenda } \\
\text { Alam Ghaib } \\
\text { - Tanjung } \\
\text { Manangis/Legenda } \\
\text { Setempat }\end{array}$ & $\begin{array}{l}\text { - Labuhan Mapin } \\
\text { - Labuhan Mapin } \\
\text { - Labuhan Mapin } \\
\text { - Labuhan Mapin } \\
\text { - Teluk Santong }\end{array}$ \\
\hline 2. & Puisi & $\begin{array}{l}\text { Jappi/ } \\
\text { Mantra } \\
\text { Kellong/ } \\
\text { Pantun }\end{array}$ & $\begin{array}{l}\text { - Siluka } \\
\text { - Pancara } \\
\text { - Lesseqko Anginge } \\
\text { - Kelong pappaseng } \\
\text { - Kelong To malolo }\end{array}$ & $\begin{array}{l}\text { - Labuhan Mapin } \\
\text { - Labuhan Mapin } \\
\text { - Labuhan Mapin } \\
\text { - Labuhan Mapin } \\
\text { Labuhan Mapin, } \\
\text { Teluk Santong }\end{array}$ \\
\hline
\end{tabular}

\section{DAFTAR PUSTAKA}

Danandjaja, James. 1997. Folklor Indonesia: Ilmu Gosip, dongeng, dan Lain-lain. Jakarta : Pustaka Grafiti.

Lathief, Halilintar. 2003. Cerita Yang Dianggukkan: Sebuah Ekspresi Tradisi Lisan Bugis. Makassar: Padat Daya. 
...Berkembang pada Masyarakat Tutur Bahasa Bugis di Kabupaten Sumbawa

Luxemburg, Jan Van dkk.. 1992. Pengantar Ilmu Sastra. Jakarta : PT Gramedia Pustaka Utama.

M.P.S.S., Pundetia. 2003. Antologi Prosa Rakyat Melayu Indonesia. Jakarta: Pusat Bahasa Depdiknas.

Pelras, Christian. 2006. Manusia Bugis. Jakarta : Nalar Indonesia/Paris.

Pradopo, Rahmat Djoko dkk. 1997. Puisi. Jakarta : Depdikbud.

Sikki, Muammad dkk.. 1996. Struktur Sastra Lisan Bugis. Jakarta : Pusat Pembinaan dan Pengembangan Bahasa Depdilbud.

Soekanto, Soerjono. 2005. Sosiologi : Suatu Pengantar. Jakarta : PT Raja Grafindo Persada.

Teeuw, A.. 1984. Sastra dan Ilmu Sastra: Pengantar Teori Sastra. Jakarta : Pt Dunia Pustaka Jaya. 